\title{
Kimberlitic sources of super-deep diamonds in the Juina area, Mato Grosso State, Brazil
}

\author{
Paulo Andreazza1, Felix V. Kaminsky², Sergei M. Sablukov², Elena A. Belousova ${ }^{3}$, \\ Mousseau Tremblay ${ }^{1}$, William L. Griffin ${ }^{3}$ \\ ${ }^{1}$ Diagem Inc., Montreal, Quebec, Canada \\ ${ }^{2}$ KM Diamond Exploration Ltd., West Vancouver, Canada \\ ${ }^{3}$ GEMOC Key Centre, Dept. of Earth and Planetary Sciences, Macquarie University, Sydney, \\ Australia
}

The Juina diamond field, in the 1970-80s, was producing up to 5-6 million carats per year from rich placer deposits, but no economic primary deposits had been found in the area. De Beers, from the midseventies to the late eighties, and Rio Tinto, between 1992 and 1997, actively explored the Juina District for kimberlite. Their respective efforts led to the discovery of 26 kimberlite bodies. Among them, was the subeconomic Collier-04 kimberlite pipe. However, the overall low grade of the different kimberlite pipes, the small size of the stones and depressed diamond prices led both companies to withdrawn from the area. In 2006-2007, Diagem Inc. discovered a group of diamondiferous kimberlitic pipes (Pandrea-1 to -7) within the Chapadão Plateau, at the head of a drainage system which has produced most of the alluvial diamonds mined in the Juina area.

\section{Geological setting}

The Juina area lies within the Tapajós Province of the Amazonian Craton. The oldest cratonic consolidation recorded in the Amazonian Craton culminated during the Early Proterozoic Transamazonian orogeny (2.25 $1.9 \mathrm{Ga}$ ), with the accretion of the Maroni - Itacaiúnas Province $(2.2-1.95 \mathrm{Ga})$ to the north and northeast of a stable Archean nucleus (>2.3 Ga) (Brito Neves et al., 1990). From Middle to Late Proterozoic, during the Uruçuano orogeny $(1.9-0.9 \mathrm{Ga})$, several mobile belts with a NW-SE structural trend accreted to each other in a northeastward direction on the southwestern edge of the central Archean nucleus to form the Amazonian Craton. The studied area lies in the Rio Negro Juruena Belt which straddles this NW-SE trend approximately $2000 \mathrm{~km}$ long and $600 \mathrm{~km}$ wide in the western portion of the Amazonian Craton.

Kimberlites were emplaced in the region and across the whole South American Platform in Brazil during the Cretaceous. At least fifteen kimberlite provinces have been recognized throughout Brazil. Most of them appear along three major continental-scale lineaments that were reactivated during the opening of the Atlantic
Ocean in Jurassic and Cretaceous times. One of the lineaments, the NW-SE striking Lineament $125^{\circ} \mathrm{AZ}$ is interpreted to be a continental extension of oceanic fractures in the South Atlantic. It encloses the Juina diamondiferous kimberlite field, among the others.

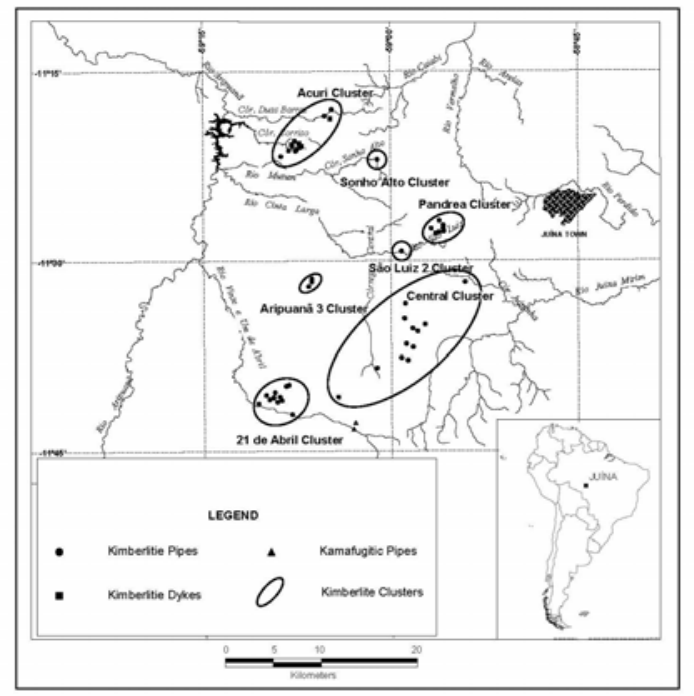

Fig. 1. Juina kimberlite field.

In total, 51 kimberlites are known to date in the Juina area including 47 pipes and 4 dykes. They are grouped in six clusters: Acuri, Sonho Alto, Sao Luis-2, Pandrea, Aripuana-3, Central and 21 de Avril (Fig. 1). The average size of the known kimberlite pipes is approximately five hectares, but they vary between 0.10 ha and 60 ha. They all are barren or weakly diamondiferous except the Collier-04 pipe, with a surface area of 16.5 ha and estimated resource of 13.9 million tonnes of kimberlite with averaging $0.40 \mathrm{ct} / \mathrm{t}$ diamond grade. Almost all kimberlitic clusters within the Juina field (except the Aripuana-3 cluster) are located at the intersections of NE- and NW-striking lineament corridors. 


\section{Pandrea (Chapadão) kimberlites}

The kimberlitic volcaniclastic rocks, forming the crater faces of the Pandrea-1 to -7 pipes in the Pandrea (Chapadão) cluster, comprise 20-30-meter visible sequences of ash-fall and/or tuffisitic material blanketed by Upper Cretaceous and Tertiary sediments. They form complex, mainly cross-bedded systems in which pyroclastic and epiclastic units are recognizable. Kimberlitic material is represented by tuffs, tuffisites and various epiclastic sediments containing chrome spinel, picroilmenite, manganoan ilmenite, zircon and diamond. The diamond grade varies from 0.2-1.8 $\mathrm{car} / \mathrm{m}^{3}$.

The magmatic component of the rocks, sometimes comprising up to $50 \%$ by volume, is represented by kimberlitic rock fragments and olivine grains fully replaced by serpentine and other secondary minerals, with a grain size of 0.2 to $3 \mathrm{~mm}$ (Fig. 2). These pseudomorphs usually have a characteristic 'parquetlike' replacement structure, which is typical of olivine replaced by serpentine

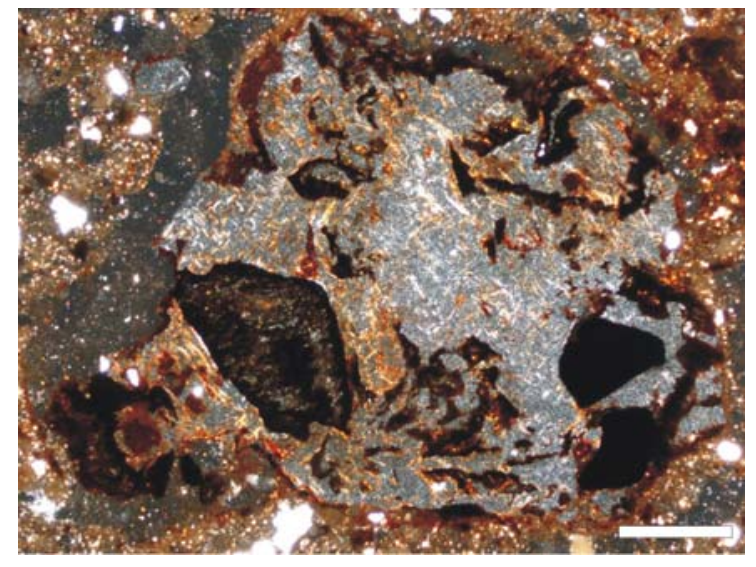

Fig. 2. Kimberlitic lithoclasts with ilmenite inclusions and pseudomorphs after olivine in kimberlitic tuffite, Pandrea-1 pipe. Scale bar is $0.5 \mathrm{~mm}$.

The heavy mineral fraction of the volcaniclastic rocks shows a quite poor spectrum of kimberlite indicator minerals that is dominated by ilmenite, with a minor admixture of chrome spinel. Chrome spinel has 30-61 wt $\% \mathrm{Cr}_{2} \mathrm{O}_{3}$; some of the chrome spinel grains are similar to chromite inclusions in diamond. Picroilmenite contains 6-14 wt \% MgO and 0.2-4 wt \% $\mathrm{Cr}_{2} \mathrm{O}_{3}$. Its composition, in Haggerty's diagram, lies within the diamond preservation field. Manganoan ilmenite has less up to $3 \mathrm{wt} \% \mathrm{MgO}$ and $0.38-1.41 \mathrm{wt}$ $\% \mathrm{MnO}$ (Kaminsky and Belousova, 2008). The ${ }^{176} \mathrm{Hf} /{ }^{177} \mathrm{Hf}$ ratio in kimberlitic zircons varies from $0.028288-0.28295$ with $\varepsilon_{\mathrm{Hf}}=5.9-8.3$, and lies on the average kimberlite trend between depleted mantle and CHUR.

Kimberlitic volcaniclastic rocks belong to the mature weathering crust, where they were very intensely altered, and the magmatic component is almost completely replaced by clay minerals. Besides, the rocks are severely contaminated by terrigenous material, primarily by quartz sand. Therefore their geochemical composition does not represent the initial composition of the kimberlitic rocks; they are very enriched in silica (55-67 wt.\% $\mathrm{SiO}_{2}$ ) and alumina (2027 wt. $\% \mathrm{Al}_{2} \mathrm{O}_{3}$ ). The highest $\mathrm{Ti}$ and $\mathrm{Fe}$ contents (up to 3.12 wt. $\% \mathrm{TiO}_{2}$ and up to 11.98 wt.\% $\mathrm{Fe}_{\text {tot }}$ ) are characteristic of kimberlites. Some trace elements show distribution characteristics similar to kimberlites (e.g., 36-160 ppm Nb and 360-660 ppm Zr).

\section{Zircon age and Hf isotopes in zircons}

$\mathrm{U}-\mathrm{Pb}$ dating of zircons was performed using a New Wave/Merchantek UP213 laser ablation system $(\lambda=213$ $\mathrm{nm}$ ) attached to an Agilent 7500cs quadrupole ICP-MS. The mean zircon ${ }^{206} \mathrm{~Pb} /{ }^{238} \mathrm{U}$ ages for zircon grains from the three pipes are almost identical, and within the analytical uncertainties:

- $\quad$ Pandrea-1 - 93.5 $\pm 0.7 \mathrm{Ma}(\mathrm{n}=12 ; 95 \%$ conf.; MSWD $=0.81$; probability 0.63$)$;

- $\quad$ Pandrea-6 - $93.7 \pm 0.7 \mathrm{Ma}(\mathrm{n}=10 ; 95 \%$ conf.; MSWD $=0.51$; probability 0.87$)$;

- $\quad$ Pandrea-7 - 93.7 $\pm 0.7 \mathrm{Ma}(\mathrm{n}=14 ; 95 \%$ conf.; $\mathrm{MSWD}=1.16$; probability 0.30 )

This allows us to consider the data from the three pipes together and calculate the average mean zircon ${ }^{206} \mathrm{~Pb} /{ }^{238} \mathrm{U}$ age for all Pandrea pipes comprising the new Chapadão cluster (Fig. 3).

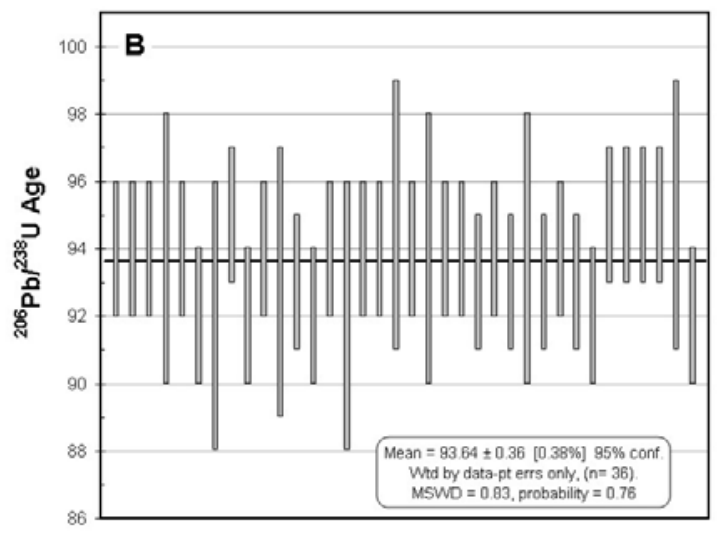

Fig. 3. Weighted mean average diagram for Juina zircon grains showing data-point errors.

For these analyses, the mean is $93.6 \pm 0.4 \mathrm{Ma}$; with a $95 \%$ confidence, MSWD $=0.83$, and probability 0.76 . This age can be considered as the age of the Pandrea kimberlitic pipes comprising the Chapadão cluster in the Juina area.

The results of Hf-isotope analyses are plotted in Fig. 4.. One can see that both the initial ${ }^{176} \mathrm{Hf} /{ }^{177} \mathrm{Hf}$ values and $\varepsilon_{\mathrm{Hf}}$ are located between the values expected for a chondritic reservoir (CHUR), and those expected for zircons crystallized from magmas with a depleted-mantle source. The Hf isotopic composition of the Juina zircons well 
corresponds to the average kimberlitic trend, according to the data of Griffin et al. (2000).

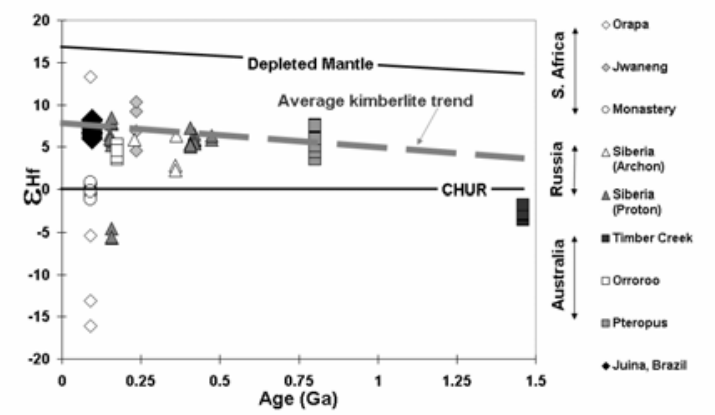

Fig. 4. $\varepsilon_{\mathrm{Hf}}$ of zircons from different localities, plotted against the intrusion age of the host kimberlites (after Griffin et al., 2000).

\section{Discussion}

The major geological difference between the earlier known, barren and weakly-diamondiferous kimberlites in the Juina area and the new ones is in their ages: the Pandrea kimberlites appear to be $93.6 \pm 0.4$ Ma old, approximately $14 \mathrm{Ma}$ older than the kimberlite ages in the Central cluster of the Juina area (80.1 Ma and 79.2 Ma; Davis, 1977). That age represents a time of magmatic reactivation related to the formation of southern part of Atlantic Ocean. The Pandrea kimberlites are Cenomanian/Turonian, more ancient than the sedimentary Cretaceous Parecis Formation. Basal conglomerates of the Parecis Formation contain diamonds (in some areas in sub-economic concentrations); this proves that the major sources of diamonds in this area are older.

The newly found Pandrea kimberlites in the Juina area, hosting super-deep diamonds that originated in the lower mantle and transition zone (Kaminsky et al., 2008) presumably originated at similar depths, and hence may be considered as the deepest known kimberlites. The mechanism of the origin of kimberlitic magma at such depth (up to $660 \mathrm{~km}$ and, possibly, deeper) is yet to be explained. There are some features of mineral inclusions in Juina diamonds (Harte et al., 1999; Kaminsky et al., 2001, 2008), such as a higher iron index in ilmenite, chrome spinel and 'olivine' than in the same phases occurring as 'usual' upper-mantle inclusions in diamond, which may reflect a process of core/mantle convection. On the other hand, some evidence may point to a possibility of super-deep subduction processes initiating partial melting of zones in the lower mantle with subsequent ascent of protokimberlitic magma. This evidence comprises inclusions of carbonates and hydrous minerals in diamonds. A nanocrystalline hydrous aluminium silicate phase $\left(\mathrm{AlSiO}_{3} \mathrm{OH}\right.$, phase 'Egg') in association with stishovite was found in one of the Juina diamonds (Wirth et al., 2007). This phase is stable at pressures at least up to $1625^{\circ} \mathrm{C}$ and $17 \mathrm{GPa}$ (Sano et al., 2004), and it may be a possible water-bearing mineral in Al-rich sediments or hydrous basalts, subducted to the depth of the transition zone or below. In other Juina diamonds, several syngenetic carbonate inclusions $20-50 \mu \mathrm{m}$ in size were found in situ in association with Cawalstromite and 'olivine' (Brenker et al., 2007). The origin of these lower-mantle carbonates is most likely related to $\mathrm{CO}_{2}$-enriched crustal or lithospheric material that has been transported to great depths via subduction processes, associated with destructive plate margins.

\section{References}

Brenker, F.E., Vollmer, C., Vincze, L., Vekemans, B., Szymanski, A., Janssens, K., Szaloki, I., Nasdala, L., Kaminsky, F., 2007. Carbonates from the lower part of transition zone or even the lower mantle: Earth and Planetary Science Letters, 260, 1-9.

Brito Neves, B.B., Texeira, W., Tassinari, C.C.G., Kawashita, K., 1990. A contribution to the subdivision of the Precambrian in South America. Revista Brasileira de Geociências, 20, 267-276.

Davis, G.L., 1977: The age and uranium contents of zircons from kimberlites and associated rocks. In: Geophysical Laboratory, Carnegie Institute, Washington Yearbook, 76, 631-635.

Griffin, W.L., Pearson, N.J., Belousova, E.A., Jackson, S.R., Van Achtenberg, E., O'Reilly, S.Y., Shee, S.R., 2000. The Hf isotope composition of cratonic mantle: LAMMC-ICPMS analysis of zircon megacrysts in kimberlites. Geochimica et Cosmochimica Acta, 64, 133-147.

Harte, B., Harris, J.W., Hutchison, M.T., Watt, G.R., Wilding, M.C., 1999. Lower mantle mineral associations in diamonds from Sao Luiz, Brazil. In: Fei, Y., Bertka, C.M. and Mysen, B.O. (Eds), Mantle Petrology: Field Observations and High Pressure Experimentation, Geochemical Society Special Publication, 6, 125-153.

Kaminsky, F.V., Belousova, E., 2008. Manganoan ilmenite as kimberlite/diamond indicator mineral. Geologia i Geofizika (Russian Geology and Geophysics) (submitted).

Kaminsky, F.V., Zakharchenko, O.D., Davies, R., Griffin, W.L., Khachatryan-Blinova, G.K., Shiryaev, A.A., 2001. Super-deep diamonds from the Juina area, Mato Grosso State, Brazil. Contributions to Mineralogy and Petrology, 140, 734-753.

Kaminsky, F.V., Khachatryan, G.K., Andreazza, P., Araujo, D., Griffin,, W.L., 2008. Super-deep diamonds from kimberlites in the Juina area, Mato Grosso State, Brazil. $9^{\text {th }}$ International Kimberlite Conference Extended Abstract No. 9IKC-A-00005.

Sano, A., Ohtani, E., Kubo, T., Funakoshi, K., 2004. In-situ X-ray observation of decomposition of hydrous aluminium silicate $\mathrm{AlSiO}_{3}(\mathrm{OH})$ and aluminium oxide hydroxide $\delta-\mathrm{AlOOH}$ at high pressure and temperature. Journal of Physics and Chemistry of Solids, 65, 15471554.

Wirth, R., Vollmer, C., Brenker, F., Matsyuk, S., Kaminsky, F., 2007. Nanocrystalline hydrous aluminium silicate in super-deep diamonds from Juina (Mato Grosso State, Brazil): Earth and Planetary Science Letters, 259, 384399. 